\title{
Pesona Sukuk Ritel Seri 13 (SR013) sebagai Alternatif Investasi di Masa Pandemi Covid-19
}

\author{
Selvia Eka Aristantia \\ Universitas Islam Negeri Sunan Ampel \\ Email: selvia.eka@uinsby.ac.id
}

\begin{abstract}
This study aims to reveal how the charm of Sukuk SR013 as an alternative investment still exists even in the midst of the Covid19 pandemic and has achieved the highest sales since online bidding was made. This study uses a netnographic method that focuses on Instagram social media. This method was chosen as a research solution in the midst of a pandemic. The netnography method is deemed suitable to be applied in this study because the researcher wants to analyze the behavior of millennial netizens on social media, especially followers of social media accounts that promote and educate about SR013. The results of this study reveal five reasons netizen investors choose to invest in this instrument. The first reason is the patriotism inherent in the souls of investors. The second reason is the benefits of getting fixed coupons. The third reason is because Retail Sukuk are traded under the concept of Sharia. The fourth reason is because of the ease of investing with a minimum investment of IDR 1,000,000.00. The fifth reason, there is clear evidence of the use of Sukuk for the country that is seen directly by investors.
\end{abstract}

Key Words: Sukuk; SBSN; Netnography; Covid-19

\begin{abstract}
Abstrak: Penelitian ini bertujuan untuk mengungkap bagaimana pesona Sukuk SR013sebagai salah satu alternatif investasi masih eksis bahkan di tengah pandemi Covid-19 dan meraih penjualan tertinggi sejak dilakukan penawaran secara online. Penelitian ini menggunakan metode netnografi yang berfokus pada media sosial Instagram. Metode ini dipilih sebagai solusi penelitian di tengah masa pandemi. Metode Netnografi dirasa relevan untuk diterapkan dalam penelitian ini karena peneliti ingin menganalisis perilaku dari netizen milenial di media sosial khususnya pengikut akun media sosial yang mempromosikan dan mengedukasi mengenai SR013. Hasil dari penelitian ini mengungkap lima alasan netizen investor memilih untuk berinvestasi di instrumen ini. Alasan yang pertama ialah adanya nilainilai patriotisme yang melekat dalam jiwa para investor. Alasan kedua ialah adanya keuntungan yang didapat dengan mendapatkan kupon tetap. Alasan ketiga karena Sukuk Ritel ini diperdagangkan dengan konsep Syariah. Alasan keempat karena kemudahan dalam berinvestasi dengan minimal investasi sebesar Rp 1.000.000,00. Alasan kelima adanya bukti nyata dari pemanfaatan Sukuk untuk Negeri yang dilihat langsung oleh investor.
\end{abstract}

Kata Kunci: Sukuk; SBSN; Netnografi; Covid-19 


\section{PENDAHULUAN}

Sejak tahun 2008, Pemerintah telah berupaya mendorong perkembangan keuangan syariah. Salah satunya ialah melalui penerbitan Surat Berharga Syariah Negara (SBSN). Sejak saat itu, SBSN telah menjadi instrumen pembiayaan dan investasi syariah yang penting. SBSN merupakan alternatif investasi yang banyak digemari, khususnya bagi kaum milenial karena SBSN memiliki beberapa keunggulan antara lain ialah Pertama, karena SBSN adalah investasi dalam negeri untuk negeri yang relatif cukup aman karena dijamin 100\% oleh negara. Oleh karenanya, banyak anak muda atau investor pemula yang belajar berinvestasi di SBSN ini. Keunggulan kedua, karena cukup aman, SBSN merupakan instrumen investasi berbasis syariah. Investasi ini juga telah disertifikasi oleh MUI sehingga, investor muslim cukup yakin untuk menyisihkan uangnya dengan berinvestasi di SBSN. Terlebih, Indonesia merupakan salah satu negara dengan jumlah penduduk Muslim terbanyak di dunia. Hal ini menjadikan Indonenesia sebagai market syariah yang besar. Keunggulan ketiga terdapat imbalan tetap yang akan dibayar tiap bulan. Keunggulan keempat karena minimum pemesanan rendah dan pajak terhadap imbalan cukup rendah dibandingan dengan instrumen investasi yang lain. Selain dari beberapa yang telah disebutkan oleh peneliti, SBSN masih memiliki berbagai keunggulan lainnya.

Salah satu kategori SBSN ini adalah Sukuk. Sukuk secara Bahasa berasal dari Bahasa Arab yang memiliki arti dokumen atau sertifikat. Menurut Peraturan Otoritas Jasa Keuangan Nomor 3 /POJK.04/2018 Tentang Perubahan Atas Peraturan Otoritas Jasa Keuangan Nomor 18/P0JK.04/2015 Tentang Penerbitan dan Persyaratan Sukuk, ${ }^{1}$ Sukuk merupakan efek Syariah berupa sertifikat atau bukti kepemilikan yang bernilai sama dan mewakili bagian yang tidak terpisahkan atau tidak terbagi (syuyu'/undivided share) atas aset yang mendasarinya. Sementara, Sukuk negara adalah Sukuk yang diterbitkan oleh pemerintah Republik Indonesia. Menurut Undang-Undang No. 19 tahun 2008 tentang Surat Berharga Syariah Negara, ${ }^{2}$ Sukuk Negara merupakan surat berharga negara yang diterbitkan berdasarkan prinsip syariah sebagai bukti atas bagian penyertaan terhadap aset SBSN, baik dalam mata uang Rupiah maupun valuta asing. Undang-undang No. 19 Tahun 2008 tentang Surat Berharga Syariah Negara juga mengatur mengenai landasan hukum penerbitan SBSN. Selain itu, Undang-Undang ini juga memberi kepastian hukum bagi investor di antaranya ialah kewajiban pemerintah dalam membayar imbalan dan nilai nominal SBSN, sanksi hukum terhadap pemalsuan SBSN serta kewajiban Menteri dalam meminta fatwa atau opini Syariah kepada DSNMUI. Undang-Undang No. 19 tahun 2008 ini memberikan koridor hukum pengelolaan SBSN yang transparan dan akuntabel. Transparan dan akuntabel dalam artian yakni jumlah SBSN yang diterbitkan setiap tahun anggaran harus disetujui oleh DPR, Selain itu, adanya koordinasi yang baik antara Bank Indonesia dan Bappenas. Perdagangan SBSN juga diatur dan harus diawasi oleh instansi berwenang.

Terdapat dua jenis Sukuk yang disediakan khusus untuk Warga Negara Indonesia yakni Sukuk Ritel dan Sukuk Tabungan. Sukuk Ritel memiliki jangka waktu 3 tahun. Sementara Sukuk Tabungan 2 tahun. Sukuk Ritel dapat

\footnotetext{
${ }^{1}$ Otoritas Jasa Keuangan, "Peraturan Otoritas Jasa Keuangan Nomor 3 /POJK.04/2018 Tentang Perubahan Atas Peraturan Otoritas Jasa Keuangan Nomor 18/POJK.04/2015 Tentang Penerbitan Dan Persyaratan Sukuk" (2018).

${ }^{2}$ Republik Indonesia, "Undang-Undang No.19 Tahun 2008 Tentang Surat Berharga Syariah Negara" (2008).
} 
diperjualbelikan di pasar sekunder setelah tiga kali pembayaran kupon. Sementara, Sukuk Tabungan tidak dapat diperjualkan di pasar sekunder namun memiliki fasilitas early redemption yakni investor memungkinkan menerima sebagian pelunasan pokok sebelum jatuh tempo berakhir. Selain itu, Sukuk Ritel memiliki fixed kupon sedangkan, Sukuk Tabungan memiliki kupon floating with floor ${ }^{3}$

Tujuan Sukuk negara diterbitkan secara langsung oleh pemerintah ialah untuk membiayai kegiatan atau proyek pemerintah yang telah dialokasikan dalam APBN seperti pembangunan infrastruktur, peningkatan pelayanan publik, pemberdayaan industrI dalam negeri serta program pemerintah lainnya yang bersifat strategis. Selain itu, proyek pemerintah tidak ditujukan untuk menghasilkan atau menghimpun pendapatan, sehingga pembayaran pokok dan imbalan untuk investor tidak bersumber dari pendapatan proyek pemerintah tersebut, akan tetapi dari penerimaan umum pemerintah dan dialokasikan tiap tahun di APBN. Hal ini tentu bermanfaat untuk meningkatkan kemandirian dalam pembiayaan pembangunan nasional sehingga dapat mengurangi ketergantungan berhutang. SBSN juga dapat mendukung percepatan pembangunan proyek infrastruktur ataupun untuk pelayanan publik.

Berdasarkan data dari DJPPR (Direktorat Jenderal Pengelolaan Pembiayaan dan Risiko), Total Project Financing Sukuk tahun 2013-2018 mencapai Rp 62.4 Triliun. Sukuk negara dipergunakan untuk pembiayan proyek antara lain pembangunan jalan dan jembatan, Pembangunan jalur kereta api di Jawa, Sumatera dan Sulawesi, Pembangunan, Proyek Sumber daya air, Pengembangan dan revitalisasi Asrama Haji, Pembangunan dan rehabilitasi KUA (Kantor Urusan Agama), Pembangunan dan pengemnangan gedung perkuliahan, Madrasah, Taman Nasional serta Laboratorium. Data ditunjukkan pada tabel berikut.

Tabel 1. Total Project Financing Sukuk tahun 2013- 2018

\begin{tabular}{|c|c|}
\hline Keterangan & Jumlah \\
\hline Jalan dan Jembatan & 30 Provinsi \\
\hline Jalur Kereta Api & $\begin{array}{c}3 \text { Pulau } \\
\text { (Jawa, Sumatera dan Sulawesi) }\end{array}$ \\
\hline $\begin{array}{l}\text { Proyek Sumber Daya Air (bendungan, } \\
\text { irigasi, penyediaan dan pengelolaan air } \\
\text { tanah) }\end{array}$ & 328 Proyek \\
\hline Pengembangan dan revitalisasi Asrama Haji & 24 Lokasi \\
\hline Kantur Urusan Agama (KUA) & 701 KUA dan Manasik Haji \\
\hline Gedung Perkuliahan & 54 Perguruan Tinggi \\
\hline Madrasah & 32 Madrasah \\
\hline $\begin{array}{c}\text { Taman Nasional (Baluran, Gede Pangrango, } \\
\text { Aketajawe-Lolobata/Halmahera) }\end{array}$ & 3 Taman Nasional \\
\hline
\end{tabular}

3 Anonym, "Mengenal Jenis-Jenis Sukuk Dan Keuntungannya," 2020, https://www.bareksa.com/berita/id/text/2020/03/04/mengenal-jenisjenis-sukuk-dankeuntungannya/24477/news.

el-Qisț: Journal of Islamic Economics and Business (JIEB) 


Laboratorium 3 Laboratorium

Sumber : Data diolah dari DJPPR

Dari total pembiayaan proyek senilai $\mathrm{Rp} 62.4$ Triliun tersebut, dapat dialokasikan ke pembangunan beberapa kementerian. Kementerian yang mendapat alokasi biaya dari Project Financing Sukuk ini ialah Kementerian Perhubungan, Kementerian Agama, Kementerian PUPR, Kementerian LH dan Kehutanan, Kemenristek, BSN serta LIPI. Data ditunjukkan pada tabel di bawah ini:

Tabel 2. Alokasi Anggaran Project Financing Sukuk

\begin{tabular}{|c|c|c|c|c|}
\hline Tahun & Kementerian & Biaya & Proyek & Total \\
\hline 2015 & Perhubungan & $\operatorname{Rp} 2.92 \mathrm{~T}$ & Pembangunan Jalur KA & \multirow{3}{*}{ Rp $7.13 \mathrm{~T}$} \\
\hline & PUPR & $\mathrm{Rp} 3.51 \mathrm{~T}$ & $\begin{array}{c}\text { Pembangunan Jalan \& } \\
\text { Jembatan (Sumatera, } \\
\text { Jawa, NTB, Kalimantan, } \\
\text { Sulawesi, Maluku, Papua) }\end{array}$ & \\
\hline & Agama & Rp $675 \mathrm{M}$ & $\begin{array}{c}\text { Asrama Haji (8 } \\
\text { Embarkasi) senilai Rp } 383 \\
\text { M, } 19 \text { KUA Rp 11M, } 7 \\
\text { PTKIN Rp 281 M }\end{array}$ & \\
\hline \multirow[t]{3}{*}{2016} & Perhubungan & $\mathrm{Rp} 4.98 \mathrm{~T}$ & $\begin{array}{l}\text { Pembangunan Jalur KA } \\
\text { Elevated \& Double Track }\end{array}$ & \multirow{3}{*}{ Rp 13.67 T } \\
\hline & PUPR & $\mathrm{Rp} 7.22 \mathrm{~T}$ & $\begin{array}{l}\text { Pembangunan jalan, } \\
\text { flyover, underpass dll }\end{array}$ & \\
\hline & Agama & $\mathrm{Rp} 1.46 \mathrm{~T}$ & $\begin{array}{c}\text { Asrama Haji (7 } \\
\text { Embarkasi) senilai Rp } \\
\text { 390M, 181 KUA Rp 183M, } \\
\text { 25 PTKIN Rp 895M }\end{array}$ & \\
\hline \multirow[t]{3}{*}{2017} & Perhubungan & Rp 7.54 T & $\begin{array}{l}\text { Pembangunan Jalur KA } \\
\text { Elevated \& Double Track }\end{array}$ & \multirow{3}{*}{ Rp 16.76 T } \\
\hline & PUPR & $\mathrm{Rp} 7.42 \mathrm{~T}$ & $\begin{array}{l}\text { Pembangunan jalan, } \\
\text { flyover, underpass dll }\end{array}$ & \\
\hline & Agama & $\mathrm{Rp} 1.79 \mathrm{~T}$ & $\begin{array}{c}\text { Asrama Haji (11 } \\
\text { Embarkasi) senilai Rp } \\
\text { 424M, 256 KUA Rp 315M, } \\
\text { 32 PTKIN Rp 1.051M }\end{array}$ & \\
\hline \multirow[t]{3}{*}{2018} & Perhubungan & Rp $7.00 \mathrm{~T}$ & $\begin{array}{l}\text { Pembangunan Jalur KA } \\
\text { Elevated \& Double Track }\end{array}$ & \multirow[b]{3}{*}{ Rp $22.53 \mathrm{~T}$} \\
\hline & PUPR & $\mathrm{Rp} 12.7 \mathrm{~T}$ & $\begin{array}{l}\text { Pembangunan jalan, } \\
\text { flyover, underpass dll }\end{array}$ & \\
\hline & Agama & $\mathrm{Rp} 2.21 \mathrm{~T}$ & $\begin{array}{c}\text { Asrama Haji (8 } \\
\text { Embarkasi) senilai Rp } \\
\text { 350M, 245 KUA Rp 355M, } \\
\text { 34 PTKIN \& } 32 \text { Madrasah } \\
\text { Rp 1.505 M } \\
\end{array}$ & \\
\hline
\end{tabular}




\begin{tabular}{ccc}
\hline $\begin{array}{c}\text { LH dan } \\
\text { Kehutanan }\end{array}$ & Rp 51 M & 3 Taman Nasional \\
\hline Kemenristek & Rp 315 M & $\begin{array}{c}\text { Pengembangan Gedung 2 } \\
\text { Perguruan Tinggi }\end{array}$ \\
\hline BSN & Rp 50 M & 1 Laboratorium \\
\hline LIPI & Rp 120 M & 2 Laboratorium
\end{tabular}

Sumber : Data diolah dari DJPPR

Dari tabel di atas, dapat diketahui bahwa proyek pembangunan Pemerintah dari tahun ke tahun selalu mengalami peningkatan. Sementara, rata-rata tertinggi pembiayaan ialah dari Kementerian PUPR untuk proyek pembangunan jalan, flyover, underpass, terowongan dan jembatan. Selain itu juga dipergunakan untuk pengendalian banjir, pengelolaan drainase, bendungan dan sebagainya. Adanya keterbukaan data pembangunan tersebut oleh Pemerintah merupakan suatu hal yang baik. Data dapat diakses melalui website oleh masyarakat secara terbuka atau transparan. Sehingga, calon investor dapat mengetahui untuk apa dan kemana perginya uang yang akan mereka investasikan untuk Negeri. Selain itu, adanya SBSN ini juga dapat memberikan kesempatan kepada kita sebagai warga Indonesia untuk menunjukkan patriotisme dengan berpartisipasi dalam membiayai pembangunan negeri. Penting adanya sikap untuk bahu-membahu bergotong royong khususnya untuk menyelamatkan Negeri di kala pandemi Covid-19 seperti saat ini.

Pandemi Covid-19 awalnya bermula dari kota Wuhan di akhir tahun 2019. Wabah Covid-19 ini memiliki tingkat penularan yang sangat cepat hingga masuk ke Indonesia sejak awal tahun, tepatnya sekitar bulan Maret paparan virus ini menyebar. Dimulai dari Jakarta hingga kini telah menyebar ke hampir seluruh kota di Indonesia. Dari 1 kasus terinfeksi hingga ratusan ribu kasus yang telah terdeteksi. Korban meninggal akibat virus Covid-19 sudah banyak berjatuhan. Banyak hal terdampak atas adanya pandemi ini. Selain masalah kesehatan, sektor ekonomi juga terdampak hingga menyebabkan resesi. Banyak perusahaan menutup usaha atau mengurangi karyawannya. Selain dikarenakan pembatasan jumlah kehadiran dalam suatu tempat karena aturan social distancing demi menurunkan angka penularan kasus Covid-19, hal ini juga diakibatkan lantaran laba yang terbilang terjun bebas. Laba menurun karena konsumsi masyarakat menurun. Konsumsi menurun karena masyarakat lebih memilih untuk tinggal di rumah sebagai upaya preventif diri. Selain itu, masyarakat lebih memilih hold money karena tidak ada kepastian kapan pandemi ini akan berakhir. Atas kecenderungan reaksi-reaksi publik yang demikian ini, pasar saham juga ikut terdampak. Adanya sensitifitas isu pandemi membuat banyak investor menarik investasinya. Bahkan ketika ada isu PSBB (Pembatasan Sosial Berskala Besar) bursa saham langsung anjlok. IHSG anjlok 5 \% (lima persen) hingga BEI terpaksa menghentikan perdagangan sementara (trading halt). Hal tersebut tertuang dalam dalam surat nomor S-274/PM.21/2020 tanggal 10 Maret 2020 yang menyebutkan bahwa trading halt akan dilakukan selama 30 menit apabila IHSG anjlok lebih dari 5\% (lima persen). ${ }^{4}$

\footnotetext{
${ }^{4}$ Mohammad fadil Supriyatna, I dan Djailani, "IHSG Ambles 5 Persen Imbas Isu PSBB Jakarta, BEI Hentikan Perdagangan,” 2020, https://www.suara.com/bisnis/2020/09/10/110231/ihsgambles-5-persen-imbas-isu-psbb-jakarta-bei-hentikan-perdagangan.
} el-Qisț: Journal of Islamic Economics and Business (JIEB) 
Adanya fenomena reaksi-reaksi negatif investor terhadap isu sensitifitas atas Covid-19 itu ternyata tidak berlaku bagi investor SBSN khususnya bagi Sukuk Ritel atau SR013 yang ditutup 23 September 2020 lalu. SR013 ini mulai ditawarkan pada 28 Agustus. Masa penawaran berlangsung selama 27 hari dan dalam masa penawaran selama 27 hari tersebut, pemerintah berhasil menetapkan hasil dari total penjualan SR013 yakni sebesar Rp 25.665.971.000.000 (Dua Puluh Lima Triliun Enam Ratus Enam Puluh Lima Juta Sembilan ratus Tujuh Puluh Satu Ribu Rupiah) yang dibeli oleh sebanyak 44.803 (Empat Puluh Empat Ribu Delapan Ratus Tiga) investor. Hal ini merupakan capaian positif ditengah pandemi karena SR013 ini justru berhasil meraih capaian penjualan terbesar dan investor terbanyak sepanjang penerbitan Sukuk ritel yang dilakukan secara online.

Dari jumlah 44.803 investor untuk SR013 ini, generasi milenial berhasil mendominasi dengan meraih investor terbanyak. Berdasarkan data dari Kemenkeu, investor terbanyak ialah generasi milenial sebanyak 36,59\% yang berkisar antara usia 19-39 tahun. Tertinggi kedua ialah generasi X sebanyak 33,50\% yang berkisar antara usia 40-54 tahun. Posisi ketiga tertinggi ditempati oleh generasi baby boomers yang berkisar antara usia 55-73 tahun yakni sebesar 26,80\%. Keempat ialah generasi tradisionalis yang berkisar antara usia 74-91 tahun yakni sebanyak 2,46\%. Terakhir adalah generasi $\mathrm{Z}$ yang berusia $<19$ tahun yakni sebesar $0,65 \%$. Data ditunjukkan pada tabel dibawah ini:

Tabel 3. Investor SR013

\begin{tabular}{ccccc}
\hline Keterangan & Usia & Presentase & $\begin{array}{c}\text { Jumlah } \\
\text { Investor }\end{array}$ & Peringkat \\
\hline Generasi Z & $<19$ tahun & $0,65 \%$ & 291 & 5 \\
\hline Generasi milenial & $19-39$ tahun & $36,59 \%$ & 16.34 & 1 \\
\hline Generasi X & $40-54$ tahun & $33,50 \%$ & 15.009 & 2 \\
\hline Generasi baby boomers & $55-73$ tahun & $26,80 \%$ & 12.007 & 3 \\
\hline generasi tradisionalis & $74-91$ tahun & $2,46 \%$ & 1102 & 4 \\
\hline Total & & $100 \%$ & 44.803 & \\
\hline
\end{tabular}

Sumber : Data diolah dari DJPPR

Pemasaran dan info SBSN sebagian besar ialah melalui media online. Hal ini dapat dikaitkan dengan tingginya angka partisipasi investor yang kebanyakan ialah generasi milenial. Dunia maya atau media online sangat dekat dengan keseharian kaum milenial. Tidak dapat dipungkiri lagi bahwa keberadaan internet atau media online sudah menggantikan media konvensional dan memberikan manfaat yang cukup besar dalam keseharian. Kaum milenial cenderung cepat mengikuti perubahan-perubahan ke versi online. Bahkan dapat dikatakan bahwa media online menjadi aktivitas untuk mengawali pagi dan mengakhiri malam. Kaum milenial tidak hanya sekedar menggunakan media online untuk sekedar mencari hiburan elektronik seperti menonton film atau mendengarkan musik. Namun, media online sekarang ini juga dapat digunakan sebagai media pembelajaran yang efektif terutama di media sosial seperti Instagram, Facebook, Youtube, Twitter dan sebagainya. Pandemi Covid-19 yang tengah terjadi ternyata tidak memberikan halhal buruk saja akan tetapi juga memberi sumbangsih positif untuk menyadarkan 
kita semua bahwa untuk belajar bisa melalui apa saja, menggunakan media apa saja dan di mana saja. Bahkan secara gratis. Ya gratis, melalui media online saat ini banyak sekali dibagikan ilmu-ilmu ataupun pembelajaran dari segala bidang ilmu secara gratis. Sehingga, sebagai generasi milenial yang cepat dan tanggap akan adanya perubahan memiliki akses yang sangat luas untuk menyerap informasi. Informasi mengenai literasi keuangan khususnya mengenai investasi SBSN SR013 ini juga banyak dilakukan edukasi dan promosi melalui media sosial.

Penelitian mengenai Sukuk telah banyak dilakukan di antaranya ialah penelitian yang membuktikan bahwa Sukuk merupakan dimensi baru pembiayaan infrastruktur pemerintah ${ }^{5}$ sekaligus untuk meningkatkan pembangunan ${ }^{6}$ dan pertumbuhan ekonomi ${ }^{7}$ yang dapat membantu mengurangi defisit APBN. ${ }^{8}$ Selain itu menurut Asiyah dkk., Sukuk juga memberikan kemanfaatan bagi likuiditas lembaga keuangan Syariah akibat dampak Covid-19 dan juga sarana investasi bagi masyarakat. ${ }^{9}$ Adapula penelitian yang menganalisis mengenai tantangan dan peluang Sukuk ${ }^{10}$ serta perspektif permintaan, penawaran dan regulasinya di Indonesia. ${ }^{11}$ Berbeda dalam penelitian-penelitian tersebut, peneliti ingin terfokus pada Sukuk Ritel 013 yang ditutup pada beberapa bulan yang lalu karena terdapat keunikan yang membungkus SR013 ini, diantaranya ialah karena SR013 ini berada dalam masa penawaran di tengah kondisi yang tidak biasa yakni Pandemi Covid-19. Di tengah ancaman resesi, namun mampu mencapai penjualan tertinggi sejak masa penawaran sukuk yang dilakukan secara online. Oleh karena itu, peneliti ingin mengungkap alasan mengenai bagaimana pesona sukuk masih dapat menerangi di kala kelabu Covid-19 menghantui Negeri.

\section{METODE PENELITIAN}

Metode merupakan suatu langkah atau cara yang diambil oleh peneliti dalam mencari temuan dari penelitian. Tentunya antara penelitian satu dengan lainnya menggunakan metode yang berbeda tergantung dari apa yang sedang dicari oleh peneliti. Peneliti dapat menentukan langkah mana yang dirasa tepat untuk disesuaikan dengan alur penelitian. Dalam penelitian kualitatif ini, peneliti memilih metode netnografi. Metode Netnografi dirasa cocok untuk diterapkan dalam penelitian ini karena peneliti ingin menganalisis perilaku dari netizen milenial di media sosial khususnya pengikut akun media sosial yang mempromosikan dan mengedukasi mengenai SR013. Selain itu, metode ini juga relevan untuk digunakan

\footnotetext{
5 Angrum Pratiwi;Dedy Mainata;Rizky Suci Ramadayanti, "Peran Sukuk Negara Dalam Pembiayaan Infrastruktur," Al-Tijary 2, no. 2 (2017): 155-76.

6 Irfan Syauqi Beik, "Memperkuat Peran Sukuk Negara Dalam Pembangunan Ekonomi Indonesia," Jurnal Ekonomi Islam Al-Infaq 2, no. 2 (2011): 65-72.

7 Bahril Datuk, "Sukuk, Dimensi Baru Pembiayaan Pemerintah Untuk Pertumbuhan Ekonomi," Jurnal Riset Akuntansi \& Bisnis Vol. $14 \quad 14 \quad$ (2014): 111-24, http://jurnal.umsu.ac.id/index.php/akuntan/article/view/159.

${ }^{8}$ Ima Amaliah and Tasya Aspiranti, "State Sukuk Potential in Reducing Indonesia Budget Deficit, 2009-2015," Journal of Economics, Business \& Accountancy Ventura 20, no. 1 (2017): 21, https://doi.org/10.14414/jebav.v20i1.781.

9 Binti Nur Asiyah; "Analisis Dampak Sukuk Pada Perekonomian Nasional Di Tengah Wabah Covid 19," El-Qist 10, no. 1 (2020).

${ }^{10}$ Dede Abdul Fatah, "Perkembangan Obligasi Syari'ah (Sukuk) Di Indonesia: Analisis Peluang Dan Tantangan," Al-'Adalah X, no. 1 (2011): 281-301.

11 Divina Mahardika Dewi et al., "Tinjauan Sukuk Korporasi Di Indonesia Dari Perspektif Penawaran , Permintaan Dan Regulasi," Journal of Business and Economic Research 1, no. 1 (2020): 11-16.
}

el-Qisț: Journal of Islamic Economics and Business (JIEB)

Vol. 10 No. 2 Oktober 2020 
di tengah kondisi Covid-19 lantaran adanya batasan-batasan akses tatap muka. Selain itu, kecepatan dalam pengumpulan informasi dengan biaya yang murah patut dijadikan alasan untuk memilih metode ini.

Netnografi (Internet Etnografi) merupakan metode yang dipelopori oleh Kozinet. Netnografi ialah salah satu dari metode kualitatif yang mengadopsi teknik riset etnografi namun dilakukan melalui mediasi online. Netnografi difokuskan pada studi mengenai media sosial. Dalam penelitian ini. Peneliti berfokus pada media sosial Instagram untuk melakukan lurking. Lurking berarti mata-mata. Dalam metode Netnografi ini, observasi peneliti dilakukan secara lurking dengan mematamatai kegiatan atau perilaku dalam komunikasi yang dimediasi secara online. Dengan melakukan lurking, peneliti berperan penting untuk mendapatkan gambaran perilaku atau kebiasaan unik dari berbagai jenis interaksi sosial yang dibangun secara online. ${ }^{12}$

Adapun beberapa tahapan dalam melakukan riset netnografi yaitu yang pertama adalah menetapkan pertanyaan penelitian, topik atau fenomena yang menggelitik keingintauan peneliti. Dalam tahap ini, peneliti mengangkat isu terkini mengenai Instrumen investasi yang cukup popular terutama di generasi milenial yakni Sukuk Ritel, yang merupakan salah satu dari instrumen SBSN. Sukuk Ritel tengah hangat diperbincangkan karena meraup angka penjualan tertinggi di tengah masa Pandemi Covid-19. Tahap kedua ialah mengidentifikasi atau menetapkan pilihan atas komunitas yang ingin diteliti. Dalam tahapan ini, peneliti mencari media sosial yang akan dipilih sebagai objek penelitian. Dalam metode ini peneliti membandingkan berbagai macam media sosial seperti facebook, twitter, youtube dan Instagram. Peneliti menetapkan pilihan dan memfokuskan penelitian pada media sosial Instagram karena dalam Instagram terdapat banyak informasi mengenai investor dan calon investor serta mitra distribusi yang mempromosikan atau mengedukasi mengenai Sukuk Ritel ini.

Tahapan ketiga ialah pengumpulan data. Pada tahapan ini, peneliti menghimpun data dan melakukan triangulasi data. Langkah keempat ialah analisis data. Dalam tahapan ini, peneliti membuat analisis domain dari data akhir yang berhasil dihimpun. Kemudian dari domain-domain yang ada peneliti menggabungkan menjadi sebuah taksonomi. Pada Analisis domain yang mengarah pada hasil taksonomi, peneliti membagi kriteria atas investor dan non investor kemudian mengambil hasil sub domain yang berupa persepsi nilai atas Sukuk yang tertuang dalam komunikasi daring yang ditangkap sebagai digital culture object. Langkah kelima atau yang merupakan langkah terakhir ialah menyajikan hasil atau temuan penelitian dalam paragraf pembahasan yang mudah dipahami ${ }^{13}$. Sehingga, hasil dari penelitian ini dapat dibaca oleh berbagai pihak, sehingga didapatkan suatu simpulan yang memberikan manfaat baik untuk institusional, pemerintah, publik ataupun penelitian selanjutnya.

\section{HASIL DAN PEMBAHASAN}

Masa penawaran yang terbatas tidak menjadikan penghalang bagi pesona sukuk ritel di masa Pandemi Covid-19. Justru kehadiran investasi SBSN ini banyak dinanti-nanti oleh netizen investor terutama di kalangan milenial. Hal ini dapat dilihat dari Total akhir penjualan yang membuktikan bahwa pesona Sukuk Ritel ini

\footnotetext{
${ }^{12}$ Robert V. Kozinets, "Netnography," The International Encyclopedia of Digital Communication and Society, 2015, 1-8, https://doi.org/10.1002/9781118767771.wbiedcs067.

${ }^{13}$ P M C Nguyen, "The Contributions of Netnography in New Product Development" (2013), https://pdfs.semanticscholar.org/f4cc/1c33b9818d27d9a83efaf166f672e3899291.pdf. 
bahkan tidak terpukul atas adanya pandemi Covid-19. Anehnya, jumlah penjualan SR013 ini merupakan hasil penjualan tertinggi sejak ditawarkan online. SR013 melambung tinggi di tengah ancaman krisis ekonomi yang digadang akan tiba menyapa Negeri ini. Hal ini merupakan pencapaian luar biasa dan tentu saja menjadi kabar yang membanggakan di tengah pandemi. Instrumen SR013 adalah instrumen Sukuk Ritel yang ke-13 kali ditawarkan. Adapun data histori penawaran atau penjualan beserta kupon yang diberikan oleh Sukuk Ritel yang dihimpun oleh peneliti sejak tahun 2009 hingga 2020 disajikan sebagai berikut:

Tabel 4. Penjualan Sukuk Ritel

\begin{tabular}{|c|c|c|c|c|}
\hline NAMA & MASA PENAWARAN & PENERBITAN & KUPON & PENJUALAN \\
\hline SR001 & 30 JAN - 20 FEB 2009 (22 hari) & 25-Feb-09 & $12.00 \%$ & $5.556 \mathrm{~T}$ \\
\hline SR002 & 25 JAN - 5 FEB 2010 (12 hari) & 10-Feb-10 & $8.70 \%$ & $8.033 \mathrm{~T}$ \\
\hline SR003 & 7 - 18 FEB 2011 (12 hari) & 23-Feb-11 & $8.15 \%$ & $7.341 \mathrm{~T}$ \\
\hline SR004 & 5- 16 MARET 2012 (12 hari) & 21-Mar-12 & $6.25 \%$ & $13.613 \mathrm{~T}$ \\
\hline SR005 & 8 - 22 FEB 2013 (15 hari) & 27-Feb-13 & $6.00 \%$ & $14.969 \mathrm{~T}$ \\
\hline SR006 & 14 - 28 FEB 2014 (15 hari) & 05-Mar-14 & $8.75 \%$ & $19.323 \mathrm{~T}$ \\
\hline SR007 & 23 FEB - 6 MAR 2015 (12 hari) & 11-Mar-15 & $8.25 \%$ & $21.965 \mathrm{~T}$ \\
\hline SR008 & 19 FEB - 4 MAR 2016 (15 hari) & 10-Mar-16 & $8.30 \%$ & $31.500 \mathrm{~T}$ \\
\hline SR009 & 27 FEB - 17 MAR 2017 (19 hari) & 22-Mar-17 & $6.90 \%$ & $14.037 \mathrm{~T}$ \\
\hline SR010 & 23 FEB - 16 MAR 2018 (22 hari) & 21-Mar-18 & $5.90 \%$ & $8.436 \mathrm{~T}$ \\
\hline SR011 & 1 MAR - 21 MAR 2019 (21 hari) & 28-Mar-19 & $8.05 \%$ & $21.117 \mathrm{~T}$ \\
\hline SR012 & 24 FEB - 18 MAR 2020 (23 hari) & 27-Mar-20 & $6.3 \%$ & $12.142 \mathrm{~T}$ \\
\hline SR013 & 28 AGUST - 23 SEPT 2020 (27 hari) & 30-Sep-20 & $6.05 \%$ & $25.667 \mathrm{~T}$ \\
\hline
\end{tabular}

Sumber : Data diolah dari DJPPR

Dari data tersebut, dapat diperoleh informasi bahwa SR013 adalah Sukuk ritel ke-13 sejak penerbitan pertama di tahun 2009. SR013 ini ternyata memiliki masa penawaran yang lebih panjang dibandingkan Sukuk ritel yang ditawarkan di tahun-tahun sebelumnya yakni selama 27 hari. Masa penawaran tersingkat adalah 12 hari yakni SR002, SR003, SR004 dan SR007. Sementara, tingkat kupon dari SR013 ini cenderung merupakan yang terendah. Namun siapa sangka justru penjualannya mencapai titik tertinggi sepanjang penawaran Sukuk yang dilakukan secara online yakni berjumlah $\mathrm{Rp} 25.665 .971 .000 .000$ yang dibeli oleh 44.803 investor. Bahkan nominal ini dua kali lipat dibandingkan total penjualan sebelumnya yakni sebesar Rp12.142.572.000.000. Di balik nominal Rp 25.665.971.000.000 ternyata tersimpan alasan bagaimana Sukuk ritel ini memiliki pesona bagi para investor, khususnya investor generasi milenial.

Berdasarkan hasil analisis yang didapat, faktor utama ialah karena adanya nilai-nilai patriotisme yang melekat dalam jiwa para investor. Hal ini membangkitkan gairah dan menggerakan semangat untuk saling bahu-membahu membangun negeri. Terlebih dalam SR013 ini, seluruh hasil investasi akan masuk dalam kas negara untuk membiayai defisit pembiayaan APBN yang kian merosot di tengah ancaman krisis akibat pandemi Covid-19. Selain itu, hasil investasi akan digunakan untuk pembiayaan penanganan dan pemulihan negeri dari Covid-19. Adanya pandemi yang dirasakan oleh banyak Negara ini justru menyulut api patriotisme warga Negara Indonesia untuk Negaranya tersebut. Hal ini tercermin dari hasil digital culture object yang menyatakan bahwa adanya SR013 ini el-Qist:: Journal of Islamic Economics and Business (JIEB) 
meningkatkan kesadaran (kepedulian) masyarakat akan pembangunan Negeri ini. Bukan hanya Pemerintah, tapi keikutsertaan masyarakat juga berperan penting dalam pembangunan Negeri. Kesadaran ini harus timbul dalam masyarakat sehingga tidak hanya sekedar mengkritisi Pemerintah ketika neraca utang luar negeri semakin bertambah akibat pandemi Covid-19 melainkan berupaya mengulurkan tangan membantu mengentaskan masalah akibat pandemi ini. Uluran tangan warga Negara, uluran tangan rakyat Indonesia. Dari negeri untuk negeri. Nilai patriotisme ini ditunjukkan oleh banyak netizen. Banyak di antaranya merasa berbangga menjadi patriot dalam kontribusi membangun negeri yang lebih baik sehingga mampu bangkit dari pandemi Covid-19.

Faktor kedua ialah adanya keuntungan yang didapat dengan mendapatkan kupon tetap dapat memberikan rasa aman bagi investor. Dari hasil analisis digital culture object, netizen menilai bahwa meskipun kupon yang diberikan dalam masa penawaran SR013 ini tergolong rendah (yakni 6.05\%) dari pada sebelumnya (6.30\%), namun kupon tersebut bersifat fixed sehingga hal tersebut masih tergolong menguntungkan jika dibandingkan dengan instrumen investasi lain yang berisiko di tengah pandemi. Bahkan jika dibandingkan dengan instrumen seperti deposito dengan bunga yang hampir menyentuh 5\% sekalipun, SR013 secara kalkulatif masih dipandang lebih menguntungkan. Investor telah menganalisis perbandinganperbandingan dari instrumen investasi di tengah pandemi covid-19. SR013 dapat menjadi alternatif dari deposito yang memiliki kupon tetap dan pajak yang dibayar juga lebih rendah (15\%) daripada pajak deposito (20\%). Dalam hal ini, meskipun instrumen Sukuk yang ditawarkan adalah instrumen syariah, dalam sudut pandang beberapa investor masih dikaburkan oleh nilai-nilai kapitalisme.

Faktor ketiga karena Sukuk ritel ini diperdagangkan dengan konsep Syariah. Hal ini memberikan nilai kepercayaan dan rasa aman (trust and safe) khususnya bagi investor Muslim yang tidak menginginkan terjerumus dalam investasi ribawi. Hal ini diperkuat dengan fatwa MUI yang memberikan label Syariah atas investasi ini. Investor bahkan meyakini bahwa angka penjualan Sukuk selalu tinggi dibandingkan dengan instrumen Surat Berharga Negara lain seperti ORI (Obligasi Negara Ritel) dan SBR (Saving Bonds Ritel) dikarenakan terdapat label Syariah. Hasil penjualan Sukuk Ritel dinilai lebih tinggi juga dibandingkan dengan Sukuk Tabungan karena Sukuk Ritel memiliki pilihan dapat diperdagangkan di pasar sekunder.

Faktor keempat karena kemudahan dalam berinvestasi dengan minimal investasi sebesar Rp 1.000.000,00. Dari digital culture object yang dianalisis, dengan nominal minimal Rp 1.000.000,00 memberikan kemudahan dalam berinvestasi di tengah kemerosotan ekonomi yang menimpa Negeri. Banyak investor yang penghasilannya berkurang sejak pandemi akibat merugi. Dengan nominal yang kecil, hal ini menjadi ketertarikan sendiri bagi investor untuk bergabung dalam investasi SR013 untuk Negeri ini. Dengan nominal yang kecil namun jika digabung akan memberikan andil yang besar atas kesuksesan penjualan SR013. Anggaplah jika minimal nominal untuk berinvestasi adalah Rp 10.000.000,00 maka belum tentu hasil penjualan yang didapat bisa sebesar ini dikarenakan syarat untuk berpartisipasi menjadi lebih tinggi. Apalagi jika yang menjadi target investasi adalah generasi milenial yang notabene-nya secara mayoritas belum memiliki kemampuan ekonomi seperti generasi X. Jadi, dengan nominal yang lebih rendah tersebut telah mampu membuka peluang untuk menjaring investor lebih banyak. Faktor kelima adanya bukti nyata dari pemanfaatan sukuk untuk Negeri yang dilihat langsung oleh investor. Adanya transparansi dari aliran investasi ini kepada publik membentuk 
kepercayaan publik untuk berinvestasi dan menimbulkan rasa bangga karena ada bagian kontribusi publik (masyarakat/rakyat Indonesia) di dalam laporan pembangunan tersebut. Transparansi ini dapat ditunjukkan dengan adanya keterbukaan pemerintah dalam memberikan informasi kepada publik atas penggunaan dana yang dihimpun dari Sukuk Ritel. Data ini dapat dengan mudah diakses publik melalui website DJPPR atau Kemenkeu. Data tersebut juga dapat diakses di berbagai media sosial akun Official DJPPR atau Kemenkeu. Bahkan salah satu dari investor menyebutkan dalam komentarnya bahwa terdapat bukti nyata pembangunan yang dilakukan oleh pemerintah atas dana yang dihimpun dari Sukuk di area kediaman investor tersebut. Sehingga investor tersebut dapat merasakan manfaat nyata atas aksi kecil yang dilakukan dengan ikut berpartisipasi dalam berinvestasi di Sukuk.

Sebaliknya, meskipun mayoritas data yang didapatkan peniliti berupa kalimat atau komentar yang positif, masih terdapat rona memudar dalam pesona Sukuk ritel. Peneliti mencatat beberapa hal dari sudut pandang non-investor dan mendapatkan hasil dari digital culture object yang dianalisis oleh peneliti yang diambil dari para non-investor yang mengaku telat mendapatkan informasi mengenai investasi ini. Hal ini disebabkan karena terdapat informasi yang kurang merata diterima oleh publik. Informasi cenderung lebih banyak di media sosial di akun-akun tertentu. Sehingga yang mendapat akses lebih banyak hanyalah generasi milenial. Sementara akses bagi generasi yang lebih tua cenderung lebih sedikit didapat karena generasi yang lebih tua biasanya kurang update terhadap media sosial dan informasi seperti ini kecuali bagi yang telah terbiasa dalam melakukan investasi atau terbiasa melakukan diversifikasi investasi. Menurut peneliti, kategori non-investor yang membutuhkan lebih banyak informasi ini adalah non-investor dengan kemungkinan terbesar untuk berubah haluan menjadi kategori investor jika mendapat informasi yang cukup dikarenakan terdapat rasa keingintahuan yang tinggi yang memungkinkan kategori ini setuju berinvestasi karena kecenderungan mendapat alasan atau keunggulan-keunggulan positif dari berinvestasi di SBSN.

Selain itu, analisis kedua memunculkan sub domain kelompok non-investor yang sedang melakukan hold money akibat kondisi tidak menentu covid-19. Dalam kategori ini ditemukan digital culture object bahwa kategori ini akan kembali berinvestasi dengan menunggu sampai keadaan berjalan dengan normal atau menunggu hingga kupon investasi yang diberikan kembali ke angka yang lebih tinggi. Sub kategori ini tergolong investor yang memiliki rasa was-was dan konservatif meskipun kategori ini mengetahui masih terdapat alternatif keuntungan meskipun sedikit tapi pasti.

Ketiga, sub domain anti trust, yang melakukan berbagai kritik terhadap Pemerintah di tengah komunikasi positif ini. Menurut peneliti, level ini yang akan paling sulit untuk berubah dari non-investor ke investor. Dalam komunikasinya, kategori ini mempercayai bahwa apa yang dilakukan oleh pemerintah selalu memberikan beban bagi rakyatnya. Rakyat yang memberi pinjaman ke Pemerintah dalam bentuk Sukuk negara, namun rakyat juga dibebankan atas kewajiban membayar pajak. Negara tidak memberikan apapun dan tidak memiliki modal apapun untuk diberikan pada rakyat. Meski sub domain anti trust ini menurut peneliti adalah yang paling sulit untuk diubah dari non-investor ke investor, peneliti berharap agar Pemerintah atau pihak mitra distribusi memberikan edukasi seluasluasnya. Sehingga cita-cita untuk menjadikan generasi yang lebih melek investasi dapat segera terlaksana dan memberikan dampak positif untuk membangun Indonesia Maju. 


\section{PENUTUP}

Hasil dari penelitian ini mengungkap bagaimana pesona Sukuk Ritel 013 tidak pudar meski di tengah pandemi justru semakin meningkat dengan jumlah penjualan tertinggi sejak dilakukan penawaran online. Dari data yang terkumpul dilakukan pemilahan domain sehingga menghasilkan analisis taksonomi yang menjelaskan hasil bahwa terdapat beberapa alasan netizen investor memilih untuk berinvestasi di instrumen ini. Alasan yang pertama ialah adanya nilai-nilai patriotisme yang melekat dalam jiwa para investor. Hal ini mempersatukan tekad untuk mengentaskan pandemi Covid-19 dari Negeri dengan berkontribusi dalam investasi. Alasan kedua ialah adanya keuntungan yang didapat dengan mendapatkan kupon tetap. Meskipun hal ini masih mengedepankan nilai kapitalisme. Alasan ketiga karena Sukuk Ritel ini diperdagangkan dengan konsep Syariah. Hal ini memberikan nilai kepercayaan dan rasa aman (trust and safe) khususnya bagi investor Syariah. Investor bahkan meyakini bahwa angka penjualan Sukuk selalu tinggi dibandingkan dengan instrumen Surat Berharga Negara lain seperti ORI (Obligasi Negara Ritel) dan SBR (Saving Bonds Ritel) dikarenakan terdapat label Syariah. Alasan keempat karena kemudahan dalam berinvestasi dengan minimal investasi sebesar Rp 1.000.000,00. Dari digital culture object yang dianalisis, dengan nominal minimal Rp 1.000.000,00 memberikan kemudahan dalam berinvestasi di tengah kemerosotan ekonomi yang menimpa negeri. Dengan nominal yang lebih rendah, hal ini mampu membuka peluang untuk menjaring investor lebih banyak khususnya generasi milenial. Faktor kelima adanya bukti nyata dari pemanfaatan sukuk untuk negeri yang dilihat langsung oleh investor. Adanya transparansi dari aliran investasi ini kepada publik membentuk kepercayaan publik untuk berinvestasi dan menimbulkan rasa bangga karena ada bagian kontribusi publik (masyarakat/rakyat Indonesia) di dalam laporan pembangunan tersebut.

Sebaliknya, terdapat pula hasil dari digital culture object yang dianalisis oleh peneliti yang diambil dari para non-investor yang mengaku terlambat mendapatkan informasi mengenai investasi karena akses informasi terbanyak hanya melalui media online. Analisis kedua memunculkan sub domain kelompok non-investor yang sedang melakukan hold money akibat kondisi tidak menentu Covid-19. Dalam kategori ini ditemukan digital culture object bahwa kategori ini akan kembali berinvestasi dengan menunggu sampai keadaan berjalan dengan normal atau menunggu hingga kupon investasi yang diberikan kembali ke angka yang lebih tinggi. Ketiga, sub domain anti trust yang melakukan berbagai kritik terhadap Pemerintah. Kategori ini mempercayai bahwa apa yang dilakukan oleh Pemerintah selalu memberikan beban bagi rakyatnya.

Berdasarkan hasil penelitian, terdapat beberapa saran yakni yang pertama untuk pemerintah atau mitra distribusi agar lebih menggencarkan edukasi terkait sukuk terutama dengan menggaet mahasiswa. Meskipun, jumlah milenial yang berpartisipasi dalam Sukuk Ritel ini lebih dominan daripada rentang usia lainnya, akan lebih baik lagi jika Pemerintah atau mitra distribusi meningkatkan angka partisipasi keseluruhan investor Sukuk Ritel. Hal tersebut dapat dilakukan salah satunya dengan mengadakan kerjasama dengan universitas-universitas. Karena berdasarkan data yang dihimpun oleh peneliti, pasar dari instrumen investasi ini masih cukup besar namun tidak banyak yang memahami secara menyeluruh dan ini butuh edukasi untuk mewujudkan generasi sadar investasi. Selain itu, pemerintah atau mitra distribusi, dapat memanfaatkan media iklan edukatif di televise yang notabene dapat diakses oleh berbagai rentang usia. Saran kedua untuk penelitian selanjutnya, diharapkan dapat menambah analisis kebaruan dengan menambah 
data-data terbaru atau menggunakan isu-isu hangat dengan menggunakan metode netnografi dikarenakan terdapat begitu banyak data yang ada di internet. Lalu lintas informasi yang cepat dapat diperoleh di internet sehingga peneliti dapat menemukan celah atau kebaruan dalam analisis penelitian selanjutnya. Penelitian selanjutnya juga dapat menganalisis instrumen investasi lain dengan menggunakan metode penelitian serupa.

\section{DAFTAR PUSTAKA}

Amaliah, Ima, and Tasya Aspiranti. "State Sukuk Potential in Reducing Indonesia Budget Deficit, 2009-2015." Journal of Economics, Business \& Accountancy Ventura 20, no. 1 (2017): 21. https://doi.org/10.14414/jebav.v20i1.781.

Angrum Pratiwi;Dedy Mainata;Rizky Suci Ramadayanti. "Peran Sukuk Negara Dalam Pembiayaan Infrastruktur." Al-Tijary 2, no. 2 (2017): 155-76.

Anonym. "Mengenal Jenis-Jenis Sukuk Dan Keuntungannya," 2020. https://www.bareksa.com/berita/id/text/2020/03/04/mengenal-jenisjenissukuk-dan-keuntungannya/24477/news.

Asiyah;, Binti Nur. "Analisis Dampak Sukuk Pada Perekonomian Nasional Di Tengah Wabah Covid 19." El-Qist 10, no. 1 (2020).

Beik, Irfan Syauqi. "Memperkuat Peran Sukuk Negara Dalam Pembangunan Ekonomi Indonesia." Jurnal Ekonomi Islam Al-Infaq 2, no. 2 (2011): 65-72.

Datuk, Bahril. "Sukuk, Dimensi Baru Pembiayaan Pemerintah Untuk Pertumbuhan Ekonomi." Jurnal Riset Akuntansi \& Bisnis Vol. 1414 (2014): 111-24. http://jurnal.umsu.ac.id/index.php/akuntan/article/view/159.

Dewi, Divina Mahardika, Lucky Nugroho, Citra Sukmadilaga, and Tettet Fitijanti. "Tinjauan Sukuk Korporasi Di Indonesia Dari Perspektif Penawaran, Permintaan Dan Regulasi." Journal of Business and Economic Research 1, no. 1 (2020): 11-16.

Faiza, Nurlaili Adkhi Rizfa, and Shafiyatun Shafiyatun. 2018. "PENGARUH NILAI OUTSTANDING SUKUK KORPORASI TERHADAP PRODUK DOMESTIK BRUTO (PDB) INDONESIA: PERIODE TRIWULANAN TAHUN 2011-2017". El-Qist : Journal of Islamic Economics and Business (JIEB) 8 (1):1577-96. https://doi.org/10.15642/elqist.2018.8.1.1577-1596.

Fatah, Dede Abdul. "Perkembangan Obligasi Syari'ah (Sukuk) Di Indonesia : Analisis Peluang Dan Tantangan." Al-'Adalah X, no. 1 (2011): 281-301.

Kozinets, Robert V. "Netnography." The International Encyclopedia of Digital Communication and Society, 2015, 1-8. https://doi.org/10.1002/9781118767771.wbiedcs067.

Nguyen, P M C. "The Contributions of Netnography in New Product Development," 2013.

https://pdfs.semanticscholar.org/f4cc/1c33b9818d27d9a83efaf166f672e389 9291.pdf.

Otoritas Jasa Keuangan. Peraturan Otoritas Jasa Keuangan Nomor 3 /POJK.04/2018 Tentang Perubahan Atas Peraturan Otoritas Jasa Keuangan Nomor 18/POJK.04/2015 Tentang Penerbitan Dan Persyaratan Sukuk (2018).

Republik Indonesia. Undang-Undang No.19 tahun 2008 tentang Surat Berharga Syariah Negara (2008).

Supriyatna, I dan Djailani, Mohammad fadil. "IHSG Ambles 5 Persen Imbas Isu PSBB Jakarta, BEI Hentikan Perdagangan," 2020. https://www.suara.com/bisnis/2020/09/10/110231/ihsg-ambles-5-persenimbas-isu-psbb-jakarta-bei-hentikan-perdagangan. 